\title{
The Impact of Cooling Ponds in North Central Texas on Dairy Farm Performance
}

\author{
M. A. Tomaszewski, ${ }^{1}$ M. A. de Haan, ${ }^{2}$ J. A. Thompson, ${ }^{3}$ and E. R. Jordan ${ }^{1}$ \\ ${ }^{1}$ Department of Animal Science, Texas A\&M University, College Station 77843 \\ 2Department of Animal Science, Wageningen University, 6709 PG Wageningen, The Netherlands \\ ${ }^{3}$ Department of Large Animal Medicine and Surgery, Texas A\&M University, College Station 77843
}

\begin{abstract}
The objective of this study was to determine whether measurable differences existed between farms with and without cooling ponds. Data from Dairy Herd Improvement records for 1999 through 2002 were obtained on 42 herds located in North Central Texas. Nineteen herds had installed cooling ponds, whereas 23 herds had not. Monthly somatic cell counts for each herd were obtained from the Federal Milk Market Administrator. Data were analyzed using the PROC MIXED regression model of SAS. Within and across herd groups, milk production from June to October was significantly lower compared with milk production for the rest of the year. Although there was numerically higher average milk production per cow per day throughout the year for herds that used cooling ponds, differences between herd groups that used or did not use cooling ponds were significant only for August production. Herds without a cooling pond had $4.8 \mathrm{~kg} / \mathrm{d}$ per cow lower production in August than in the coolseason months of November to May (26.4 \pm 0.6 vs. 31.2 $\pm 0.5 \mathrm{~kg} / \mathrm{d}$ ), whereas the difference in August production was only $2.9 \mathrm{~kg} / \mathrm{d}$ per cow in herds that used cooling ponds $(29.0 \pm 0.7 \mathrm{vs} .31 .9 \pm 0.6 \mathrm{~kg} / \mathrm{d})$. Differences caused by seasonal use of a cooling pond in culling, days to first service, days open, percentage of estruses observed, and somatic cell counts were not significant. Bulk tank milk samples cultured for 10 different bacteria showed no difference between cooling pond and noncooling pond herds in 2002. Also, there was no difference in incidence of violations from the Texas Department of Health for herds that used or did not use cooling ponds. However, herds with cooling ponds did have a lower percentage of successful breedings, fewer days dry, and a higher percentage of cows in milk compared with dairy herds that used other forms of cooling. Such differences may or may not be attrib-
\end{abstract}

Received May 5, 2004.

Accepted February 21, 2005.

Corresponding author: M. A. Tomaszewski; e-mail: mat@dairy. tamu.edu. uted to seasonal use of a cooling pond. Therefore, cooling ponds may provide relief from heat stress without adversely affecting most important measures of herd performance.

(Key words: dairy management, cooling pond, heat stress, culling)

Abbreviation key: FMMA = Federal Milk Market Administrator, $\mathbf{T D H}=$ Texas Department of Health.

\section{INTRODUCTION}

Heat stress is a major impediment to efficient production of milk in the Southern states of the United States. At temperatures $>25^{\circ} \mathrm{C}$, cows use energy to cool themselves through heat loss via their surface skin and respiratory tract. As ambient temperatures and relative humidity increase, it becomes more difficult for cows to cool themselves adequately (Armstrong, 1994). High-producing cows are most sensitive to heat stress because of their high feed intake (Jones and Stallings, 1999).

According to the National Weather Service (2003), the normal daily maximum temperature in North Central Texas is $>25^{\circ} \mathrm{C}$ from May until October. Normal daily maximum temperature exceeds $32.2^{\circ} \mathrm{C}$ between June and August. Normal relative humidity in this area ranges from 60 to $70 \%$. These temperature and humidity ranges result in temperature-humidity index levels such that dairy cows in North Central Texas suffer from mild heat stress in April, May, and October and medium heat stress in June, July, August, and September.

One method of cooling cows in the Southern states of the United States is to use a cooling pond. A cooling pond is defined as a dynamic, man-made structure managed to preserve its dynamic state by the addition of water to maintain a set water level based on cow movement and environmental conditions. Water must flow into the cooling pond at a rate that ensures maintenance of the water level $\geq 91.4-\mathrm{cm}$ minimum design depth (Jordan et al., 2003). Bray et al. (1989) showed that internal temperature of cows dropped 0.5 to $1^{\circ} \mathrm{C}$ within a few minutes after entering the pond. Bray et 
al. (1989) conducted a study in Florida and found that, during the use of a cooling pond, milk production did not drop, as is usually the case. In the same study, SCC was elevated a little compared with other seasons, but was not significant. In a survey of Florida herds, the least squares means for SCC was lower in herds with man-made ponds than in herds without cooling ponds (Bray et al., 1989). In addition, the average DIM also increased for the cows that used the pond.

Access to streams and farm ponds has been associated with a number of infectious diseases and some toxicities in dairy cattle (Shearer et al., 1987). It was suggested that ponds might pose a risk to dairy cattle health because of the often poor quality of the water. Ponds could increase the incidence of mastitis and elevate SCC in a herd (Garcia, 2002). Studies conducted in Florida and Texas found that man-made cooling ponds had no apparent adverse effect on udder health (Shearer et al., 1999; Jordan et al., 2003). During the period from July until September, the incidence of clinical mastitis for cows exposed to ponds was one-half of that observed for cows with no access to ponds (Shearer et al., 1999). Bray et al. (1989) found no increase in clinical mastitis associated with pond use. Shearer et al. (1999) concluded that cows from herds with regularly maintained man-made ponds produced milk with lower SCC compared with cows from herds with no access to man-made or natural ponds. Those researchers concluded that proper pond maintenance must accompany their use.

The objective of this study was not to evaluate heat abatement procedures per se, but rather to determine whether differences existed between herds that did or did not have a cooling pond for certain measures of production, udder health, health, and management.

\section{MATERIALS AND METHODS}

To determine the extent of cooling pond usage in North Texas, a survey was sent to all Grade A milk producers in that area. Fifty-five producers indicated they had a pond. Of the respondents, 28 were also enrolled in DHIA. Because the majority of the herds were located in Archer and Clay counties in North Central Texas, the study was limited to that area, thus removing geographical bias. Seventy-seven DHI herds in that area comprised the initial data set. To be included as a cooling pond herd, the pond had to be in place before the summer of 2000. Also, the herd had to be continuously enrolled in DHI for the $4 \mathrm{yr}$ of the project. After 22 herds were deleted because of incomplete data, a total of 55 herds located in the restricted geographical area were classified based on whether they used cooling ponds as a means of supplemental
Table 1. General characteristics for herds included in the data set.

\begin{tabular}{llll}
\hline Cooling pond & Herds (no.) & Herd size & Milk per day \\
\hline No & 23 & 192 & 29.8 \\
Yes & 19 & 243 & 30.9 \\
\hline
\end{tabular}

cooling to alleviate heat stress. Data included monthly DHI values for each herd as calculated by the Dairy Records Management Systems. The Federal Milk Market Administrator (FMMA) collected monthly SCC on all Texas herds, and SCC data were obtained from this agency. To have complete data on all herds in the DHIA and FMMA databases, another 13 herds were excluded. The final database contained 19 herds with a cooling pond and 23 herds without a cooling pond. Data from cooling pond herds before installation were not included in the data set. In June, July, August, and September of 2002, twice-monthly bulk tank samples were collected and cultured (Jordan et al., 2003). During this same period, a list of violations from the Texas Department of Health (TDH) was also received.

Herds that used cooling ponds had 51 more cows on average than herds that did not use cooling ponds; average milk production was not significantly different (Table 1). Cooling ponds are used during the summer period, and cows have free choice to use the pond. The 'no' herds do not have a cooling pond, but all herds could have had other heat abatement procedures that were used during this study.

The highest temperature-humidity index occurred in August and the surrounding months. Seasons were grouped as August, June-July, September-October, and all other months (nonsummer). The data represented both fixed and random effects; data were analyzed using a PROC MIXED regression model (Littell et al., 1996) of SAS (SAS Institute, Inc., 2001). Cooling pond, season, and their interactions were analyzed as fixed effects, and herd was a random effect. It was possible to analyze the within-herd effect of season because each herd had all 4 levels of season. However, the effect of ponds was assumed to affect entire herds. Thus, the outcome of primary interest, for our overall objective, was the interaction of season and cooling pond.

For the variables expressed as percentages (culling, successful breedings, observed estruses, and cows in milk), the PROC UNIVARIATE of SAS (SAS Institute, Inc., 2001) was used to determine the median and mean. Residuals were evaluated for the model assumptions, including normality of random effects and individual effects using the likelihood ratio $\chi^{2}$. 
Table 2. Least squares means and standard errors for effects of cooling ponds on production per milking cow per day by season.

\begin{tabular}{|c|c|c|c|c|c|c|}
\hline & \multicolumn{6}{|c|}{ Cooling pond } \\
\hline & \multicolumn{2}{|c|}{ Yes } & \multicolumn{2}{|c|}{ No } & \multicolumn{2}{|c|}{ All } \\
\hline & LSM & $\mathrm{SE}$ & LSM & $\mathrm{SE}$ & LSM & $\mathrm{SE}$ \\
\hline Jun.-Jul. & $29.6^{\mathrm{a}, \mathrm{c}}$ & 0.6 & $28.2^{\mathrm{a}, \mathrm{c}}$ & 0.6 & $28.9^{\mathrm{c}}$ & 0.4 \\
\hline Aug. & $29.0^{\mathrm{a}, \mathrm{c}}$ & 0.7 & $26.4^{\mathrm{b}, \mathrm{c}}$ & 0.6 & $27.7^{\mathrm{c}}$ & 0.4 \\
\hline Sep.-Oct. & $29.5^{\mathrm{a}, \mathrm{c}}$ & 0.6 & $28.2^{\mathrm{a}, \mathrm{c}}$ & 0.6 & $28.9^{\mathrm{c}}$ & 0.4 \\
\hline Other & $31.9^{\mathrm{a}, \mathrm{d}}$ & 0.6 & $31.2^{\mathrm{a}, \mathrm{d}}$ & 0.5 & $31.5^{\mathrm{d}}$ & 0.4 \\
\hline All & $30.0^{\mathrm{a}}$ & 0.6 & $28.5^{\mathrm{a}}$ & 0.5 & & \\
\hline
\end{tabular}

${ }^{\mathrm{a}, \mathrm{b}}$ Means within reference row with different superscripts differ in cooling pond effect $(P<0.05)$.

${ }^{\mathrm{c}, \mathrm{d}}$ Means within reference column with different superscripts differ in season effect $(P<0.05)$.

\section{RESULTS AND DISCUSSION}

\section{Milk Production}

The main effect of cooling ponds showed that herds using cooling ponds were numerically higher producing herds, producing an average of $1.5 \mathrm{~kg} / \mathrm{d}$ of milk per cow throughout the year more than herds without cooling ponds, but this difference was not significant (Table 2). Armstrong (1994) reported milk production in Texas cows to normally decrease in the summer period because of heat stress. The current report shows a similar effect. The 5 mo of expectecd heat stress resulted in significantly lower milk production than the other months $(129 \mathrm{~kg} / \mathrm{yr})$. Although production was lowest in August, it was not significantly different than the 2 mo before or after August for cooling pond herds. However, herds without cooling ponds had significantly lower production in August when compared with herds that used cooling ponds (Table 2).

There was a highly significant interaction (effect modification) for cooling ponds by season. Model estimates for milk per cow per day illustrate that the summertime drop in milk production was larger in herds without cooling ponds. Relative to nonsummer, milk production in herds with cooling ponds decreased by $2.9 \mathrm{~kg} / \mathrm{d}$ per cow in August, $2.3 \mathrm{~kg} / \mathrm{d}$ per cow in June and July, and $2.4 \mathrm{~kg} / \mathrm{d}$ per cow in September and October. The herds without cooling ponds had significantly larger seasonal decreases including $4.8 \mathrm{~kg} / \mathrm{d}$ per cow in August, $2.9 \mathrm{~kg} / \mathrm{d}$ per cow in June and July, and $3.0 \mathrm{~kg} / \mathrm{d}$ per cow in September and October. The potential for bias exists in these data as demonstrated by our analysis of the main effects of cooling ponds. In this observational study, managers of higher producing herds had adopted this cooling technique. The cooling ponds are drained and not used in nonsummer months; therefore we do not propose that cooling ponds were necessarily a causative factor in the higher production observed in these herds. Although the potential for bias exists, we have reported that higher pro- duction is generally related to larger seasonal effects. Thus, we reason that the resulting estimates for the effectiveness of cooling ponds will be biased toward the null effect and, thus, may underestimate the effectiveness of cooling ponds, particularly because we did not include classification of other cooling systems that were in use on some farms.

\section{Management}

Two management variables, percentage of cows in milk and number of days dry, differed by herd group. Percentages of cows in milk for farms with cooling ponds were higher than for farms without a cooling pond ( 88.1 vs. $86.4 \pm 0.5 \% ; P<0.05$ ). Average numbers of days dry for farms with cooling ponds were lower than for farms with cooling ponds (63.9 vs. $70.6 \pm 2.0$ d; $P<0.05$ ). There were no seasonal differences for either variable (data not shown); thus, management factors, other than having a cooling pond, likely accounted for those differences.

\section{Culling}

Data were grouped into 2 major classes for animals leaving a farm; died vs. all other reasons (Table 3). The total of cows that died and those that left for another reason was defined as percentage left for the DHI test interval processed. Percentages of cows that left the herd were treated as a normal distribution, and no significant differences in percentages of cows culled for the 2 farm groups were found. Although there was a significant difference in the cows culled in June and July vs. all other month combinations, it was not related to the use of a cooling pond. Herds that used cooling ponds did not cull cows differently than herds without a pond. The average yearly total percentage of cows that left the farm was $33.5 \%$ for herds that did not use cooling ponds and $31.3 \%$ for herds that used them. 
Table 3. Least squares means and standard errors for effects of cooling ponds on percentage died or culled for other reasons by season.

\begin{tabular}{|c|c|c|c|c|c|c|c|c|c|c|c|c|}
\hline & \multicolumn{12}{|c|}{ Cooling pond } \\
\hline & \multicolumn{6}{|c|}{ Yes } & \multicolumn{6}{|c|}{ No } \\
\hline & Died & SE & Other & $\mathrm{SE}$ & Total & $\mathrm{SE}$ & Died & SE & Other & SE & Total & SE \\
\hline Jun.-Jul. & $0.4^{\mathrm{a}, \mathrm{c}}$ & 0.1 & $1.8^{\mathrm{a}, \mathrm{c}}$ & 0.3 & $2.1^{\mathrm{a}, \mathrm{c}}$ & 0.3 & $0.3^{\mathrm{a}, \mathrm{c}}$ & 0.1 & $1.6^{\mathrm{a}, \mathrm{c}}$ & 0.3 & $1.9^{\mathrm{a}, \mathrm{c}}$ & 0.3 \\
\hline Aug. & $0.5^{\mathrm{a}, \mathrm{d}}$ & 0.1 & $1.9^{\mathrm{a}, \mathrm{d}}$ & 0.5 & $2.4^{\mathrm{a}, \mathrm{d}}$ & 0.5 & $0.5^{\mathrm{a}, \mathrm{d}}$ & 0.1 & $2.9^{\mathrm{a}, \mathrm{d}}$ & 0.4 & $3.4^{\mathrm{a}, \mathrm{d}}$ & 0.4 \\
\hline Sep.-Oct. & $0.5^{\mathrm{a}, \mathrm{d}}$ & 0.1 & $2.3^{\mathrm{a}, \mathrm{d}}$ & 0.3 & $2.7^{\mathrm{a}, \mathrm{d}}$ & 0.3 & $0.5^{\mathrm{a}, \mathrm{d}}$ & 0.1 & $2.5^{\mathrm{a}, \mathrm{d}}$ & 0.3 & $3.0^{\mathrm{a}, \mathrm{d}}$ & 0.3 \\
\hline Other & $0.5^{\mathrm{a}, \mathrm{d}}$ & $<0.1$ & $2.7^{\mathrm{a}, \mathrm{d}}$ & 0.2 & $3.2^{\mathrm{a}, \mathrm{d}}$ & 0.2 & $0.4^{\mathrm{a}, \mathrm{d}}$ & 0.0 & $2.5^{\mathrm{a}, \mathrm{d}}$ & 0.2 & $2.9^{\mathrm{a}, \mathrm{d}}$ & 0.2 \\
\hline All & $0.5^{\mathrm{a}}$ & $<0.1$ & $2.2^{\mathrm{a}}$ & 0.2 & $2.6^{\mathrm{a}}$ & 0.2 & $0.4^{\mathrm{a}}$ & 0.0 & $2.4^{\mathrm{a}}$ & 0.2 & $2.8^{\mathrm{a}}$ & 0.2 \\
\hline
\end{tabular}

${ }^{\mathrm{a}, \mathrm{b}}$ Means within reference row with different superscripts differ in cooling pond effect $(P<0.05)$.

${ }^{\mathrm{c}, \mathrm{d}}$ Means within reference column with different superscripts differ in season effect $(P<0.05)$.

\section{Reproduction}

Dry cows, whose last 3 mo of gestation occur during hot weather, may have calves with smaller birth weights and more metabolic problems postpartum. In addition, they produce $12 \%$ less milk in the next lactation. Conception rate was lower because of less activity during estrus, reduced follicular activity, and early embryonic death (Jones and Stallings, 1999). Cooling dry cows enhanced their ability to successfully transition into a new lactation (Bray and Bethard, 2000). Wiersma and Armstrong (1989) conducted a heat stress study in Saudi Arabia and found significantly higher numbers of cows culled for reproductive failure in the control group than in the group containing cows cooled prepartum.

Reproduction was analyzed for percentage of successful breedings, average days open to first service, average days open, and percentage observed estruses (Table 4). Because DHI data were used for these analyses, potentially some difference could be attributed to reporting discrepancies. Overall significant differences between groups of herds that did or did not use cooling ponds were found only for percentage of successful breedings $(P<0.05)$. The estimate for successful breedings for cooling pond herds was $37.0 \%$ and without a pond $46.3 \%$, with differences consistently observed throughout the year. One explanation could be a greater use of bulls for natural service in herds that did not use cooling ponds (30.4\% vs. $21.9 \%)$. With more use of natural service, fewer unsuccessful inseminations are reported, thereby raising the percentage of successful breedings when such cows are diagnosed pregnant. This explanation was supported by the fact that there were no differences in average days to first service, average days open, nor percentage of observed estruses. In other studies using DHI data (Washburn et al., 2002), herds with a high percentage of successful breedings have been excluded because of the high probability of incomplete breeding records. In this study, 2 herds that used cooling ponds and 2 herds that did not use cooling ponds were bred using natural service. Because of the limited number of herds identified with and without cooling ponds in the defined geographical area, these herds were not excluded, as it would have compromised the remainder of the analysis. The per-

Table 4. Least squares means and standard errors for effects of cooling ponds on reproduction measures by season.

\begin{tabular}{llllllllll}
\hline & $\begin{array}{l}\text { Cooling } \\
\text { pond }\end{array}$ & $\begin{array}{l}\text { Successful } \\
\text { breeding } \\
\text { percentage }\end{array}$ & SE & $\begin{array}{l}\text { Average days to } \\
\text { first service }\end{array}$ & SE & $\begin{array}{l}\text { Average } \\
\text { days open }\end{array}$ & SE & \multicolumn{3}{c}{$\begin{array}{l}\text { Percentage of } \\
\text { observed } \\
\text { extruses }\end{array}$} & SE \\
\hline Jun.-Jul. & Yes & $38.3^{\mathrm{a}, \mathrm{c}}$ & 3.5 & $92.2^{\mathrm{a}, \mathrm{c}}$ & 4.4 & $162.6^{\mathrm{a}, \mathrm{c}}$ & 5.9 & $39.2^{\mathrm{a}, \mathrm{c}}$ & 3.2 \\
& No & $48.9^{\mathrm{b}, \mathrm{c}}$ & 3.2 & $100.1^{\mathrm{a}, \mathrm{c}}$ & 4.0 & $163.2^{\mathrm{a}, \mathrm{c}}$ & 5.4 & $35.4^{\mathrm{a}, \mathrm{c}}$ & 3.0 \\
Aug. & Yes & $34.2^{\mathrm{a}, \mathrm{c}}$ & 4.1 & $92.1^{\mathrm{a}, \mathrm{c}}$ & 4.5 & $165.6^{\mathrm{a}, \mathrm{c}}$ & 6.2 & $32.8^{\mathrm{a}, \mathrm{c}}$ & 3.7 \\
& No & $44.8^{\mathrm{a}, \mathrm{c}}$ & 3.7 & $100.5^{\mathrm{a}, \mathrm{c}}$ & 4.1 & $166.8^{\mathrm{a}, \mathrm{c}}$ & 5.9 & $30.9^{\mathrm{a}, \mathrm{c}}$ & 3.4 \\
\multirow{2}{*}{ Sep.-Oct. } & Yes & $38.3^{\mathrm{a}, \mathrm{c}}$ & 3.5 & $90.9^{\mathrm{a}, \mathrm{c}}$ & 4.4 & $168.3^{\mathrm{a}, \mathrm{c}}$ & 5.9 & $32.5^{\mathrm{a}, \mathrm{c}}$ & 3.3 \\
& No & $44.0^{\mathrm{a}, \mathrm{c}}$ & 3.3 & $100.0^{\mathrm{a}, \mathrm{c}}$ & 4.0 & $169.0^{\mathrm{a}, \mathrm{d}}$ & 5.4 & $34.2^{\mathrm{a}, \mathrm{c}}$ & 3.1 \\
& Yes & $37.2^{\mathrm{a}, \mathrm{c}}$ & 3.2 & $93.5^{\mathrm{a}, \mathrm{c}}$ & 4.3 & $165.5^{\mathrm{a}, \mathrm{c}}$ & 5.8 & $46.9^{\mathrm{a}, \mathrm{d}}$ & 3.0 \\
& No & $47.5^{\mathrm{b}, \mathrm{d}}$ & 2.9 & $101.1^{\mathrm{a}, \mathrm{c}}$ & 3.9 & $165.6^{\mathrm{a}, \mathrm{c}}$ & 5.3 & $44.0^{\mathrm{a}, \mathrm{d}}$ & 2.8 \\
& Yll & $37.0^{\mathrm{a}}$ & 3.2 & $92.2^{\mathrm{a}}$ & 4.3 & $165.5^{\mathrm{a}}$ & 5.3 & $37.8^{\mathrm{a}}$ & 3.0 \\
& Yos & $46.3^{\mathrm{b}}$ & 2.9 & $100.4^{\mathrm{a}}$ & 3.9 & $166.1^{\mathrm{a}}$ & 5.8 & $36.1^{\mathrm{a}}$ & 2.8 \\
\hline
\end{tabular}

${ }^{\mathrm{a}, \mathrm{b}}$ Means within reference with different superscripts differ in cooling pond effect $(P<0.05)$.

${ }^{\mathrm{c}, \mathrm{d}}$ Means within reference with different superscripts differ in season effect $(P<0.05)$. 
Table 5. Least squares means and standard errors for effects of cooling ponds on log SCC (Federal Milk Market Administrator data) by season.

\begin{tabular}{lllll}
\hline & \multicolumn{4}{c}{ Cooling pond } \\
\cline { 2 - 5 } & Yes & SE & No & SE \\
\hline Jun.-Jul. & $5.0^{\text {ac }}$ & 0.1 & $5.0^{\text {ac }}$ & 0.1 \\
Aug. & $5.1^{\text {ac }}$ & 0.1 & $5.1^{\text {ac }}$ & 0.1 \\
Sep.-Oct. & $4.9^{\text {ac }}$ & 0.1 & $4.9^{\text {ac }}$ & 0.1 \\
Other & $4.7^{\text {ad }}$ & 0.1 & $4.8^{\text {ad }}$ & 0.1 \\
All & $4.9^{\mathrm{a}}$ & 0.1 & $5.0^{\mathrm{a}}$ & 0.1 \\
\hline
\end{tabular}

${ }^{\mathrm{a}, \mathrm{b}}$ Means within reference with different superscripts differ in cooling pond effect $(P<0.05)$.

${ }^{\mathrm{c}, \mathrm{d}}$ Means within reference with different superscripts differ in season effect $(P<0.05)$.

centage of successful breedings tended to decrease in August, but season effect was not significant nor was the cooling pond by season interaction. Consequently, no impact on percentage of successful breedings could be conclusively attributed to cooling ponds.

There were no differences between average days to first service. Seasonal interactions were also not different, indicating that cooling ponds did not affect that variable. For average days open, overall there was no difference in the 2 groups, but there was a difference in September and October between those that used or did not use cooling ponds. However, this difference was relatively small and might have been an artifact. Although overall there was no difference in percentages of observed estrus associated with use of cooling ponds, there was a difference between the warm months compared with the rest of the year. During the summer period, the percentage of observed estruses was lower, which agreed with Hansen et al. (1992) who showed a large decrease in pregnancies in summer months in lactating dairy cattle. In general, there was little impact of cooling ponds on reproductive variables.

\section{Milk Quality Indicators}

Somatic cell counts were transformed logarithmically (Table 5). Analysis of the FMMA's bulk tank SCC data revealed significant seasonal differences with summer months having significantly higher bulk tank SCC. This increase was similar to that observed in all Texas herds based on the bulk tank SCC reported by the FMMA (FMMA, 2004). However, the seasonal increase in bulk tank SCC did not differ between herds with and without cooling ponds $(P>0.05)$. Bray (2000) also concluded that ponds did not increase clinical mastitis.

Milk tank samples were collected twice monthly during June, July, August, and September in 2002 and once monthly for February, March, April, May, and October. The only bacteria that showed any prevalence were Streptococcus agalactiae or Streptococcus nonagalactia between herds that did or did not have cooling ponds, and the difference was not significant. This result agrees with Bray (2000), who reported no unusual organisms were treated in herds that had cooling ponds. Also, there was no difference in violations found by the TDH between herds that did and did not have cooling ponds. Similarly, Bray (2000) found that milking cows with access to man-made cooling ponds had lower standard plate count and direct microscopic SCC counts than other herds in Florida with no access to ponds and that herds with natural ponds were higher in both categories. Similarly, our results showed no adverse health effects. Thus, because SCC, bacterial culture, and violations do not increase with the use of cooling ponds, it appears they can be used without compromising milk quality.

\section{CONCLUSIONS}

Using a cooling pond on a farm may benefit both animal welfare and production for areas where heat stress is a problem without compromising milk quality. A cow using a cooling pond, regardless of any other cooling system in place, is estimated to produce $129 \mathrm{~kg} /$ yr more than a cow that does not. Differences caused by seasonal use of a cooling pond in culling, reproduction, and SCC were not significant. Differences for herds with a cooling pond are higher production, lower percentage of successful breedings, fewer days dry, and a higher percentage of cows in milk compared with dairies that used other forms of cooling. There was no difference in bulk tank SCC or in violations found by the TDH between groups of herds that did or did not have ponds.

\section{REFERENCES}

Armstrong, D. V. 1994. Heat stress interaction with shade and cooling. J. Dairy Sci. 77:2044-2050.

Bray, D. R. 2000. Cooling ponds for dairy cattle. Fact sheet DS96, Anim. Sci., Florida Coop. Ext. Serv., Inst. Food Agric. Sci., Univ. Florida.

Bray, D. R., and G. Bethard. 2000. Dry cow cooling. Pages 20-31 in Proc.Heart of America Dairy Management Conf., KS. Kansas State Univ., Manhattan, KS.

Bray, D. R., M. A. DeLorenzo, F. C. Elvinger, D. K. Beede, J. K. Shearer, P. A. Reed, and J. Boosinger. 1989. Cooling ponds and milk quality. Pages 63-72 in Proc. 26th Annu. Florida Dairy Production Conf., Tampa, FL. Univ. of Florida, Gainesville, FL.

Federal Milk Market Administrator. 2004. Texas and New Mexico Market Component Test. The Market Administrators Report XXX (6):5. Online. Available: http://www.dallasma.com/. Accessed Jul. 13, 2004.

Garcia, A. 2002. Dealing with heat stress in dairy cows. Coll. Agric. Biol. Sci., South Dakota Univ., Extension Extra 4024. 
Hansen, P. J., W. W. Thatcher, and A. D. Ealy. 1992. Methods for reducing effects of heat stress on pregnancy. Pages 116-125 in Large Dairy Herd Management. H. H. Van Horn and C. J. Wilcox, ed. American Dairy Science Association, Champaign, IL.

Jones, G. M., and C. C. Stallings. 1999. Reducing heat stress for dairy cattle. Dep. Dairy Sci., Virginia Tech. Univ. Publication Number 404-200.

Jordan, E. R., T. Hickerson, and M. Tomaszewski. 2003. Evaluation of the effects of cooling ponds on bacterial population in bulk tank milk samples. Pages 316-317 in Proc. 42nd Annu. Natl. Mastitis Counc. Conf., Fort Worth, TX. Natl. Mastitis Counc. Madison, WI.

Littell, R. C., G. A. Milliken, W. W. Stroup, and R. D. Wolfinger. 1996. SAS System for Mixed Models. SAS Inst., Inc. Cary, NC.

National Weather Service. DFW Annual Summary of Normal, Means, and Extremes. Online. Available http://www.srh.noaa.gov/fwd/CLIMO/dfw/normals/dfwann.html. Accessed Feb. 18, 2003
SAS User's Guide. Statistics, Version 8.2. Ed. 2001. SAS Inst., Inc. Cary, NC.

Shearer, J. K., D. R. Bray, and R. A. Bucklin. 1999. The management of heat stress in dairy cattle: What we have learned in Florida. In Proc. Feed Nutr. Manage. Cow Coll., Virginia Tech. Univ. Blacksburg, VA.

Shearer, J. K., D. R. Bray, F. C. Elfinger, and P. A. Reed. 1987. The incidence of clinical mastitis in cows exposed to cooling ponds for heat stress management. Pages 66-70 in Proc. 26th Annu. Natl. Mastitis Counc. Conf., Orlando, FL. Natl. Mastitis Counc., Madison, WI.

Washburn, S. P., W. J. Silvia, C. H. Brown, B. T. McDaniel, and A. J. McAllister. 2002. Trends in reproductive performance in southeastern Holstein and Jersey DHI herds. J. Dairy Sci. 85:244-251.

Wiersma, F., and D. V. Armstrong. 1989. Evaporative cooling of dry cows for improved performance. In Arizona Dairy Newsletter (Jul.):1-5. 